\title{
Editorial
}

\section{Net destiny global brand hell - unless communications practitioners value risk more transparently}

\section{VISION IMPOSSIBLE, SHOULD YOU ACCEPT IT?}

In 2006, Brand Chartering ${ }^{1}$ celebrates its tenth anniversary. The book was the first in the genre of living and learning the brand, and now has at least ten companion books to my knowledge. As readers of this journal in its early years will know, Brand Chartering was conceived around the brand transparency and goodwill human relations system principles of:

- Organisational learning architecture: what questions should every discipline serving the brand be conversing around so that the brand (architecture) earns the trust of all its constituencies and through time rewards all who serve it most competently?

- Drama of leadership alignment: how do we develop a common living script that everyone in the organisation has access to and updates with 'do-now' changes and clarifications of what we urgently need to investigate anew?

In developing the first version of Brand Chartering, the integration of three main practice perspectives was researched:

- media and cultural roles of identification;
- intranet and intrapreneurial roles of the people who are core to an organisation's social map, so energising co-workers to interact brand and knowledge flows;

- direction of the organisation's investment in branding and other systemwide architectures of leadership.

It is appropriate to issue the first ten-year report on Brand Chartering in this journal, in a brief format which summarises the main action learning curve experiences that Brand Chartering's journey has taken practitioner circles on. Our weblog ${ }^{2}$ provides free downloads of the handbook's 12 original Q\&A workshops and thinkpad, and a fourth row of questions designed to rectify incidences of unseen wealth $^{3}$ crisis where boardrooms have no integral measures of the future exponentials they are compounding.

\section{LANGUAGE TIMEWARPS AND INCONVENIENT TRUTH}

Back in 1984, I co-authored a future history $^{4}$ on the first global generation (1984-2024) with my father, then Deputy Editor of The Economist. The book completed a trilogy whose earlier surveys had been published in The Economist as 'The coming entrepreneurial revolution' (1976), and 
'We're all intrapreneurial now'5 (1982). Mapping death of distance forecast the internet as the greatest ever communications and transport revolution ${ }^{6}$ - one which would spin extraordinary innovation waves ${ }^{7}$ around which humanity would need to collaborate if the 21st century was to turn out to be the best of times. As we reach half-time in developing what the globalisation system spins, it is timely to charter what we actually mean by brand, markets, economics etc. One way to start chartering marketing's sustainability begins with the question: what are the inconvenient truths ${ }^{8}$ of marketing? Here are some of my replies against which you can measure yours.

\section{Inconvenient truth 1}

There are many definitions of marketing. When I first made market modelling my career in the 1970s, I was idealistic enough to assume that we all work for marketing with the aim of improving people's lives over time. That remains the only leadership valuation purpose that I have time for. The core construct of marketing that has always most interested me is Peter Drucker's, as detailed in his Practice of Management (1956) — where you will find that he assessed only marketing and innovation as valuable, while regarding all other processes of organisation as costs. Recall that 1956 was effectively before television's advertising age had taken hold. In Drucker's book, hard-working people want to spend their working lives doing stuff inside an organisation that is related to demands from outside the organisation as well as gravitated by the core purpose of the whole organisational system. His definition of market- ing is about understanding outside demands so that people inside can most simply improve how they do their jobs. As I recall, Harvard's Theodore Levitt used to be marketing's very own Drucker - with his language celebrating the duty of marketing to revolve round continuous improvement, to prevent myopia and so forth. And in Britain, Hugh Davidson ${ }^{9}$ has consistently rallied the visionary goals around which marketing can align good-willed organisations. His latest book interviewed leaders of all types of large organisations. Over 100 in all, and less than a third of them expressed a vision that he could remember the day after and that would have had attracted him if he had been young again and applying for a job in that sector. We may infer that many organisations have become so boxed in by micromanaging spreadsheets that they are specialising in becoming organisational learning retards. In the USA, for example, employee surveys show that most no longer believe they regularly get a chance to use their greatest talents. I have a dream: a time when societies will start to demand that we grade leadership teams 'AA' where they are sustaining organisational learning and junk status where they are not. In parallel, the chief economist at the Work Foundation ${ }^{10}$ can model how in most developed countries it is now the case that poor productivity is seldom a worker problem, but a signal that management or systemisation is poor.

\section{Inconvenient truth $\mathbf{2}$}

Many veteran practitioners know that any medium that works has a period when its good value tends not to be sustained as the medium gets crowded 
and popularity causes a lemming-like rush to throw budget at it, however costly it gets. I spent most of the 1980 s working in 30 countries with the first database market modelling software. The method was licensed to our French headquartered company for worldwide use outside of the USA by MIT professors (model names: Assessor — simulated test markets, Perceptor positioning maps, Designor - concept to market tracking). By the end of the 1980s, the alarming signal from our databases was that most of the world's largest multinationals were going all the way through the new product development process, targeting business cases that needed twice the market share possible in a crowded market - something only possible with a breakthrough innovation - yet less than 2 per cent of about 3,000 new product developments monitored were of that order. In other words, immediately prior to the birth of the mass personal computing age, most large organisations had a lurking crisis with innovation. ${ }^{11}$

\section{Inconvenient truth $\mathbf{3}$}

You can always milk any brand platform to get great looking quarterly results for a few quarters at the cost of diluting trust in and quality of the brand more than anyone gained. I have actually helped several companies model how to take over market leadership from incumbents who milked their right to leadership.

\section{Inconvenient truth $\mathbf{4}$}

Drucker's modus of valuation implies that we need a model of a flow that is systemic, that connect disciplines and business units so that customers and societies' experiences are whole and not less than the parts, as well as sustaining goodwill exponentials over time. However, when the spreadsheet arrived, and five accountants went global, they faced an awkward fact that goodwill had become a huge black hole not matching any of accounting's standard metrics. To preserve their monopoly measurement role in the boardroom, they split intangibles into bits: brand, knowledge, investment in training people, etc. This was the biggest mathematical error ever to have been institutionalised because intangibles value flows through connectivity. Consider an organisational system mapped as tense human relationships of productivity and demand spinning either virtuously or viciously. This is all you need to do to see that the accountant had no clue of how human relationships multiply - otherwise, when faced with business stakeholder value of billions going up and societal value heading down to zero, it would not have made leadership decisions as if these amounts were separately additive. Goodwill is multiplicative billions times 0 heads to 0 , not billions $+0$

\section{Inconvenient truth $\mathbf{5}$}

In the new economy's intangibles world of service economy and learning networks, cash flow and tangibles are the odd measures out. They are the only ones that add as the sum of their parts. Intangibles are the living system flows that never sum as they are always multiplying to be more or less than their parts. The consequences of not understanding how goodwill's compound 
dynamics multiply over time become ever more risky, especially when networks as systems ${ }^{\star}$ systems $^{\star}$ systems propagate any such risks globally and at every locality.

\section{CAN CHARTERING NETWORKS SHED FURTHER LIGHT ON THESE INCONVENIENT TRUTHS?}

The answer is yes, but let me be frank, when I was writing up Brand Chartering in 1994-1995, I did not have deep experience of these issues at that time, so the handbook published in 1996 provides few warnings about them.

Overall, Brand Chartering 1996 ranked the most connected question of living scripting as the understanding of brand essence we can discover by asking: what would the world uniquely miss if this brand ceased to exist tomorrow?, probe by every branch and relevant segment of stakeholders. I had not anticipated, however, that this question is often too deep to start a true brand investigation. If the corporation has any irreconcilable conflicts between stakeholders, this question will expose them. This can cause great distress at the top of the company, often manifested by firing the brand charterer and anyone who's been working with them. An Indonesian variant of this that I personally experienced was: 'now you have started, your team had better finish the job under armed protection because we are new owners of this company and we need to know where the corrupt managers are'.

One worldwide brand consultancy who licensed brand chartering fixed this problem with this rather neat exercise: ask top managers which of the main chartering questions they are happy for all levels of the organisation to participate in. Having got this advance warning, they could then work out if there was any brand integrity work that was still worth doing in terms of narrowing the gap between brand image-making and brand reality-making.

I have had the chance to get feedback on early versions of these findings at Harvard, ${ }^{12}$ Dartmouth and Georgetown ${ }^{13}$ in the USA and various marketing educators' conferences in the UK. On condition of anonymity, one professor said to me: 'the problem is that what you are talking about criss-crosses so many disciplines that in academia today none of our separated disciplines will get funding to study it'. As a low-cost experiment, we formed a senior practitioner network with biannual retreats, which led to the book Beyond Branding. ${ }^{14}$ According to the review made in Argent, the journal of The Financial Services Forum, this book: 'challenges, in a very practical way, the narrow, short-termist, shareholder-focused approach to marketing that drives many companies today'. Fussy I may be, but I'd score this review as 9 out of 10 as I'd prefer we used the term 'speculator-focused', because true investors are often the biggest losers of all of the take from the last quarter, regardless of the future metrics monopoly.

I decided to put brand chartering on the backburner until I had developed the minimum mathematics needed to see what conflicts exist between all the coordinates of productivity inputs and stakeholder outputs. From early 2002, all cases of total corporate devaluations have fitted around the mapping coordinates provided to transparency mapmakers ${ }^{15}$ through open source use (Figure 1). 


\begin{tabular}{|c|c|c|c|}
\hline $\begin{array}{l}\text { Do organisational } \\
\text { measures contextually } \\
\text { gravitate unique } \\
\text { organisational purpose? } \\
\text { Truth reasoning: an } \\
\text { organisation cannot lead } \\
\text { anywhere unique if it has } \\
\text { no context-specific } \\
\text { measure of its biggest } \\
\text { goal overriding rewards } \\
\text { of all the standardised } \\
\text { measures. }\end{array}$ & $\begin{array}{l}\text { Is organisation } \\
\text { consciously valuing } \\
\text { trust-flow? } \\
\text { Trust-flow begins every } \\
\text { cycle by detecting } \\
\text { emerging conflicts or } \\
\text { disconnects. Emotionally } \\
\text { intelligent organisations } \\
\text { encourage this relentless } \\
\text { search both because } \\
\text { environments change } \\
\text { and as productive } \\
\text { systems are always tense } \\
\text { but need to be healthily } \\
\text { so. }\end{array}$ & $\begin{array}{l}\text { Is organisation } \\
\text { transparent with } \\
\text { networking dependent } \\
\text { partners (both business } \\
\text { and societies)? } \\
\text { In a networking age, } \\
\text { boundaries are every } \\
\text { organisation greatest } \\
\text { new risk.* Organisations } \\
\text { have lost all their value } \\
\text { because of a partner's } \\
\text { carelessness; conversely } \\
\text { more and more of the } \\
\text { world's greatest } \\
\text { tragedies can be mapped } \\
\text { as having been } \\
\text { externalities waiting to } \\
\text { happen. }\end{array}$ & $\begin{array}{l}\text { Does leadership team } \\
\text { understanding that strategy } \\
\text { has to be adapted to } \\
\text { which future exponential } \\
\text { (goodwill or badwill) the } \\
\text { system is spiralling? } \\
\text { In service and learning } \\
\text { economies, strategies do } \\
\text { not implement unless } \\
\text { people relate to them. } \\
\text { When an organisation is } \\
\text { full of conflicts, most } \\
\text { strategies have no chance } \\
\text { of implementing } \\
\text { however much money or } \\
\text { power is thrown at them. }\end{array}$ \\
\hline
\end{tabular}

* Compelling evidence of the need in a networking age to internalise a global sector's most risky externality is given by CEOs on both sides of the Atlantic. See, for example, Sir John Banham in the UK, and Ray Anderson in Atlanta (http://www.rsa.org.uk/acrobat/anderson_050505.pdf).

Figure I Brand Chartering thinkpads now navigate around a fourth row of Q\&A

To pull this all together, transparency mapmaking and value multiplication exchange theory of the networking firm is currently being written up by a senior journalist of marketing. A fundamental pattern rule of any human relations system is that it is always spinning - either sustainably up or viciously down. Depending on how conflict-free is the quality between the relationship coordinates, we can value ahead of time what future exponential a corporation is compounding. We can also grade the transparency of the governance ${ }^{16}$ that its executives are being offered by their professional advisors and auditors. Any brand charterer can host a roundtable game integrating up to ten different role-players representing the main flows of knowledge working productivity (individual, group, sys- tem structured, global market networked, local society resourced) and the five main stakeholder demand streams (employees, customers, owners, what progress vision the global market sector is truly about, local societies' sustainability rights).

To survive and flourish, organisations must create win-win relationships with the people they deal with. This is the underlying purpose of every business: to organise and connect different groups of people (customers, employees, investors, distributors, partners etc) in a collaborative quest for a particular form of mutual value creation. Most thoughtful business leaders are well aware of this, yet rarely make profitable use of their knowledge for one simple reason: no one has yet managed to translate this rather abstract and generalist insight 


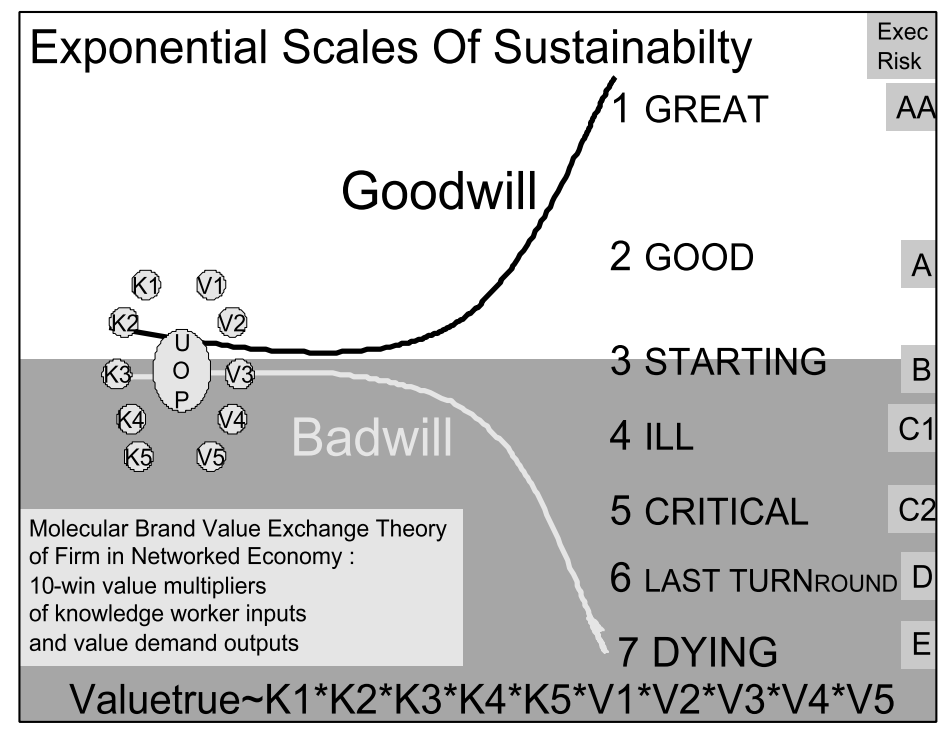

Figure 2 Galley review of THE MAP

into concerted, practical action - at least until now. Value multiplication mapping does just that, providing professionals with the tools they need to discover the value of the people, knowledge, networks, culture, behaviours, brands, communities, and learning that forms the basis of today's corporate value measurement (Figure 2). ${ }^{17}$

\section{WHY NOT CATALOGUE A HISTORY OF TESTIMONIES ON VALUATION ERRORS}

I look back on the 1990s as my decade of great naivety. Before Brand Chartering, I had written World Class Brands ${ }^{18}$ in 1990. On both publishing occasions, I joined one of the largest professional firms who had sounded eager for an innovative approach only to find that they wanted to turn the methodology's transparency entirely on its head. However, I did learn some incredible stuff - such as reading one-hour interviews of the top 50 leaders of a global professional firm a couple of years before they shredded all their goodwill. I also came to see serial evidence of a vicious side effect of globalisation. Professions licensed by societies to be responsible for a monopoly to write up the rules have increasingly lost their 'do no evil' Hippocratic oaths, as expert David Maister also appears to confirm. ${ }^{19}$ So I started looking out for fellow testifiers, travelling round the world to interview them if they would permit me to log up their experience. Naomi Klein of No Logo and Margaret Blair of Unseen Wealth, Verna Allee of Value Exchange Theory of Knowledge20 were sensational.

Remarkable in a different way were the testimonies of a couple of European Union research funds managers who explained how unlikely politicians are to do anything about the intangibles valuation crisis unless the people stand up and compel them to. Inconvenient democratic questions: Will the implosion of pensions lead to a public rising around trust-flow and transparency exponentials? How many 
more externalisation disasters do we all have to suffer before we remedy accounting mathematics that is perfect only insofar as it governs how to compound mistrust, as well as booking in investments in machines while charging all people as costs that must be cut. And then there was the head of a global branding practice at one of the blue-chip management consultancies who told me: 'we only use branding as an issue to play on any CEO's biggest insecurity and to sell in something else'.

As ordinary people with families, we can also look at this from the viewpoint of taking a reality check on 21 Global Market Sectors for Century 21. It turns out that the simplest way to ask whether the power of globalisation is spinning sustainably or the compound opposite, is not to question responsibility $^{21}$ at individual corporate levels but whole global market sector levels. In many cases, these are determined primarily by how a cluster of five to ten of the biggest organisations behave regarding the risk to human life that the sector has more in-depth knowledge on, than anyone else can have. Have a look at this list of global sectors - how many would you stake your grandchildren's futures on as being sustainable, let alone compounding the progress humanity most wants the sector to truly focus on. Put another way, we need to step back and ask of the current globalisation design: is humanity turning on itself? ${ }^{22}$ Which global market sectors most concern your family's futures and which way are their sustainability exponentials heading? Typical people's lists often start with fine-tuning a composite list like this:
1. National governance

2. City or local governance (and 2 million global village inter-trading)

3. Water

4. Energy

5. Media

6. MBA education

7. Education of children

8. Healthcare

9. Healthy food chain

10. Global retail

11. Safety and network resilient homeland security

12. Law simplified and periodically adaptive

13. Professional Hippocratic oaths

14. Insurance

15. Banks with profit models other than indebtedness

16. Long-term pensions/savings industries

17. Computers and telecoms investments in people

18. Bottom of pyramid preneurs connecting digital and historic divides

19. Uniting nations and cultures interlocally around 30,000 projecthumanity initiatives

20. Travel industries

21. Great next-to-be invented open source or abundance market sectors

\section{PREVENTING RISKS OF GLOBAL BRAND HELL}

If there is a possibility that globalisation's singularity is drowning us in a media and a mediation crisis, what can we the people do about it? I would very much like to hear from you at c.m.macrae.72@cantab.net if you are concerned about one of more of these sectors. I can offer to host a free 
conflict resolution game - role-played virtually - if we can find a few people who are deeply involved in a particular sector and able to map both the service and demand sides.

Meanwhile, I will be piloting a survey of shareholders of The Economist on what they see as the future vision of economics as well as their brand. The survey is probably replicable for other disciplines' main media if you have access or interest to explore this.

Below is an extract of our 1984 script on the role we had imagined that the BBC could cheerlead in giving public broadcast media a world service lead in connecting the nest of their scale with the best of the internet's such and iterative weblinking discussions. If you feel like joining a network that writes letters to the governors of the $\mathrm{BBC}$, see http://www.pledgebank.com/bbcgames.

By 2005 the gap in income and expectations between the rich and poor nations was recognised to be man's most dangerous problem. Internet linked television channels in sixty-eight countries invited their viewers to participate in a computerised conference about it, in the form of a series of weekly programmes. Recommendations tapped in by viewers were tried out on a computer model of the world economy. If recommendations were shown by the model to be likely to make the world economic situation worse, they were to be discarded. If recommendations were reported by the model to make the economic situation in poor countries better, they were retained for 'ongoing computer analysis' in the next programme.

In 2024 it is easy to see this as a forerunner of the TC conferences which play so large a part in our lives today, both as pastime and principal innovative device in business. But the truth of this 2005 breakthrough tends to irk the highbrow. It succeeded because it was initially a rather downmarket network television programme. About 400 million people watched the first programme, and 3 million individuals or groups tapped in suggestions. Around 99 per cent of these were rejected by the computer as likely to increase the unhappiness of mankind. It became known that the rejects included suggestions submitted by the World Council of Churches and by many other pressure groups. This still left 31,000 suggestions $^{23}$ that were accepted by the computer as worthy of ongoing analysis. As these were honed, and details were added to the most interesting, an exciting consensus began to emerge. Later programmes were watched by nearly a billion people as it became recognised that something important was being born.

The word 'entrepreneur' ${ }^{24}$ seems to be a brand that can help reform economics or at least clarify whose assumptions are lording over us with numbers. Macrae-nets have been working with a family tree of types of entrepreneurial revolutionaries for over 30 years now, and we'd happily share our maps of who's who if this interests you. For example, in October 2005 a networking event on organisational democracy ${ }^{25}$ connected a few hundred people. We heard ten companies testify to the service economy's intrapreneurial golden triangle. This was noted specifically by Bill Tailor, founder of Fast Company magazine, like this: connect the goodwill of employees with serving and learning from those fussy customers whose depth of need also best understands what society wants next from the sector you are in.

Amazing value multiplication can happen when machine-age management gets over itself and wholly empowers services' golden triangle. In 
the case of South West Airlines, for shareholders who have sustained their investment in the brand for a generation, more wealth (100-fold returns) has been compounded than any other US stock-marketed company, but only because even more wealth has been multiplied for the main society that South West serves. Thirty years ago, the airline figured that the home regions it served in the USA would be cut off from the centres of business development unless it provided people with the most user-friendly airline flying possible.

In the USA, the investment reformations that excite me most are connected to the term 'social entrepreneur', and are closely linked to the aforementioned emergence of sustainability investment, and to microfinance movements. The innovation spaces $^{26}$ people use to start mapping this connect around the map of Bill Drayton's 28-year long networking of 1,500 social entrepreneurs linking inter-local entrepreneurs' projects across over 50 countries.

Finally, two children's and youth education networks I am interested in joining and exploring have started up around these two weblogs: http://er100.blogspot.com and http://ninenow.blogspot.com (my daughter is nine, so there's lots of new learning networks to map: http://www.frappr.com/younghubs).

\section{Chris Macrae Editorial Board}

\section{References}

(1) Chris Macrae and co-workers of the World Class Branding Network (1996) 'Brand Chartering Handbook - How Brand
Organisations Learn Living Scripts', Economist Intelligence Unit and Addison-Wesley.

(2) http://brandchartering.blogspot.com.

(3) 'Unseen Wealth: Report of the Brookings Task Force on Intangibles', Co-Chairs Steven Wallman and Margaret Blair (2001), Brookings. See also http://www. euintangibles.net which exposed a lot of high-risk cases before the leadership questions it was raising were regarded as too hot for the EU to fund. Parallel knowledge angels networks exploring the connections between intellectual, human, social and other intangibles capitals were also closed down when it was found that they sided on human views of knowledge work instead of a knowledge management that prioritises investment in machines (http://kmeurope.blogspot.com). In Japan, a senior member of the knowledge management community is conducting research into the 'learning slavery' of various governments' biases against funding learning organisation research which values human intelligence as different from machine intelligence.

(4) Macrae, N. and Macrae, C. (1984) 'The 2024 Report', Sidgwick and Jackson.

(5) http://www.normanmacrae.com/ intrapreneur.html .

(6) http://deathofdistance.blogspot.com - this future history genre now has a variety of names including the million book best-seller by Thomas Friedman (2005) 'The World is Flat' and more being co-edited by correspondents at http://clubofbethesda. blogspot.com.

(7) http://www.valuetrue.com/home/ gallery.cfm.

(8) Al Gore has made a movie Inconvenient Truth observing the system breakdown risks we are taking on climate, as well as helping to innovate the sustainability investment industry — see http://www.bbc.co.uk/ dna/actionnetwork/A4205819 and http://www.socialedge.org/ events\%20resources/032106/algore.html. Back in 1984, photosynthesis of clean energy was the first of seven crisis waves we forecast as connecting humanity in collaborative innovation between 2000 and 2015. Over 22 years of searching, we have been mapping networkers most concerned with its solution at http://algaeworld. blogspot.com. Four more crisis waves (http://globalcharters.blogspot.com) relate to media from the learning network perspectives of what we need to teach our 
children, to transparency of conflict resolution, to introducing the antidote to unseen wealth and loss of touch of professions with serving society.

(9) Davidson, H. (2002) 'The Committed Enterprise - How to Make Vision and Values Work', Butterworth-Heinemann. The 2004 paperback edition changed the subtitle to 'Making Vision, Values and Branding Work'.

(10) http://www.theworkfoundation.com/.

(11) Organisational transformation facilitators have a convincing explanation for this. Major organisation-wide innovation actually requires many sides and top people to move simultaneously through innovation's conflict barrier, giving up habits (eg those budget expenditures that once worked but no longer do). For 25 years now this systemic internal marketing intervention has been practised by over 1,000 alumni of Harrison Owen's Open Space technology - but how many marketing text books map this as a vital thread of innovation success? See http://openspaceraces. blogspot.com.

(12) Macrae, C. (1999) 'Towards a value exchange theory of Brand Trust', Journal of Marketing Management; presentation available from author.

(13) At the global marketing colloquium in Georgetown 2000, I presented the emerging white paper, 'The coming wars between goodwill and badwill networks'. This developed into more formal talks at the annual meeting of the risk professional association Survive (London, 2003) and one of the primary economic papers at the Global Reconciliation Network meeting in Delhi, 2004; see http://globalreconciliationnetwork.org and http://goodwillwars.blogspot.com.

(14) Ind, N. et al. 'Beyond Branding', available at: http://www.beyond-branding.com.

(15) http://valuetrue.blogspot.com and http://www.valuetrue.com.

(16) http://intangibles-valuation.blogspot.com.

(17) Draft available for authors via Chris Macrae at c.m.macrae.72@cantab.net.

(18) Macrae, C. (1991) 'World Class Brands', Addison-Wesley. An early interview on brands as mediators of our times saw The Economist's survey of 1988 as 'The Year of The Brand'. Journalist John Micklethwait, now editor of The Economist, concluded his investigation of trust in global branding's corporate leadership responsibilities with Shakespeare's quotation: What's in a name? That which we call a rose, By any other word would smell as sweet'.

(19) http://www.fastcompany.com/magazine/ 58/shortcourse.html.

(20) http://www.vernaallee.com.

(21) Journal of Brand Management (2002), Special Issue - Total Brand Corporate Responsibility.

(22) Queen Elizabeth II, end of 2005 message to Commonwealth.

(23) http://project30000.blogspot.com.

(24) http://entrepreneurialrevolution. blogspot.com and http://social-entrepreneur.blogspot.com.

(25) The host of Organisational Democracy was Traci Fenton of http://www.worldblu.com.

(26) www.ashoka.org, www.changemakers.net, and Bornstein, D. (2004) 'How to Change the World - Social Entrepreneurs and the Power of New Ideas', Oxford University Press, Oxford. 